UDC 351.851(477)

DOI: https://doi.org/10.32689/2617-

2224-2019-17-2-25-33

Vavrenyuk Sergey Anatolievich, PhD in Public Administration, Doctoral candidate of Educational, Scientific and Production Center of the National University of Civil Defense of Ukraine, 61023, Ukraine, Kharkiv, Str. Chernysherska, 94, tel.: (057) 70031 71, e-mail: sergei-vavrenyuk@nuсzu. edu.ua

ORCID: 0000-0002-6396-9906

Вавренюк Сергій Анатолійович,

кандидат наук з державного управління, докторант навчально-науково-виробничого центту Національного університету иивільного захисту Украӥни, 61023, Україна, м. Харків, вул. Чернишевська, 94, (057) 70031 71, e-mail: sergei-vavrenyuk@nuczu. edu.ua

ORCID: 0000-0002-6396-9906

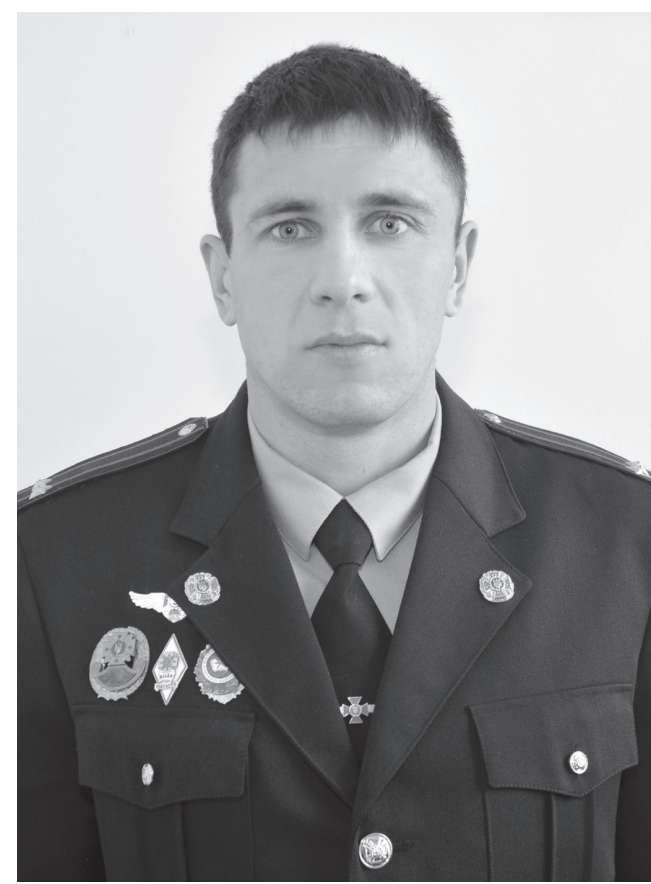

Вавренюк Сергей Анатольевич,

кандидат наук по государственному управлению, докторант учебно-научно-производственного центра Национального университета гражданской защиты Украины, 61023, Украина, г. Харьков, ул. Чернышевская, 94, (057) 70031 71, е-таil: sergeivavrenyuk@nuczu.edu.ua

ORCID: 0000-0002-6396-9906

\title{
FEATURES OF GOVERNMENTAL REGULATION IN THE SPHERE OF EDUCATIONAL SERVICES OF UKRAINE
}

Abstracts. The article reveals the problem of state regulation of higher education in Ukraine. First of all, attention is focused on the process of European integration when choosing the features and directions of development of higher education in the country.

The author examines the concept of public administration and the concept of education in the light of the ongoing process of reform in the field of educational services, in particular - higher education in Ukraine. It is noted that public administration is designed to meet the educational needs of society, thereby achieving the strategic goals of its development and the economy as a whole. At the same time, education acts as an object of executive power and is characterized by inte- 
gration with the entire social system, which in turn requires the implementation of state regulation for its organization.

The article focuses on the fact that public administration should be directed at regulating the organization of the educational process, controlling the quality of education, as well as establishing the procedure for licensing and state accreditation of institutions of higher education. Thus, the author points to the important role of higher education management in Ukraine.

The author also determines and studies the executive authorities in the field of public administration of education, names their functions and basic powers in relation to the provision of educational services in the country. Defining the tasks of state educational authorities, the author conducts a comparative analysis with European countries and the characteristics of their institutional and functional state of public administration of the higher education system.

In conclusion, the author notes the main problem areas in the domestic experience of public administration of the higher education system, calling among them the lack of autonomy of higher education institutions and the low level of activity of public advisory bodies, which are designed to create recommendations for the development of the country's higher education system, thereby making it more effective and quality.

Summing up, the author determines that for the implementation of the organizational and legal mechanism of public administration of higher education it is necessary to consistently perform organizational and legal actions that rely on objective laws and are aimed at reforming the education system.

Keywords: education system, higher education, public administration, quality of education, education reform, the process of European integration.

\section{ОСОБЛИВОСТІ ДЕРЖАВНОГО РЕГУЛЮВАННЯ У СФЕРІ ОСВІТНІХ ПОСЛУГ УКРӒ̈НИ}

Анотація. Розкрито проблему державного регулювання вищої освіти України. Акцентується увага на процесі євроінтеграції під час вибору особливостей та напрямів розвитку вищої освіти в країні.

Розглядаються поняття державного управління й освіти як процесу реформування, що відбувається у сфері освітніх послуг, зокрема - вищої освіти України. Визначено,щодержавнеуправлінняпокликанезадовольнятиосвітні потреби суспільства для досягнення стратегічних цілей його розвитку та економіки загалом. При цьому освіта виступає об'єктом виконавчої влади та характеризується інтеграцією з усім суспільним устроєм, що, своєю чергою, вимагає виконання державного регулювання за ії̈ організацією.

Акцентується увага на тому, що державне управління має спрямовуватися на регулювання порядку організації навчального процесу, контролювати якість освіти, а також встановлювати порядок ліцензування та державної акредитації закладів вищої освіти. Тим самим наголошується на важливій ролі управління вищою освітою в Україні. 
Зокрема, визначено та вивчено органи виконавчої влади у сфері державного управління освітою, їх функції та основні повноваження щодо надання освітніх послуг у країні. Визначаючи завдання державних органів управління сферою освіти, здійснено порівняльний аналіз з європейськими країнами та особливостями їх інституційного та функціонального стану державного управління системою вищої освіти.

Окреслено проблемні місця у вітчизняному досвіді державного управління системою вищої освіти, а саме - відсутність автономності закладів вищої освіти та низький рівень діяльності громадських консультативних органів, покликаних створювати рекомендації щодо розвитку системи вищої освіти в країні, що сприятиме їі ефективності та якості.

У підсумку визначається, що для реалізації організаційно-правового механізму державного управління вищою освітою необхідно послідовно здійснювати організаційні та правові дії, які спираються на об'єктивні закони і спрямовані на реформування системи освіти.

Ключові слова: система освіти, вища освіта, державне управління, якість освіти, реформування освіти, процес євроінтеграції.

\section{ОСОБЕННОСТИ ГОСУДАРСТВЕННОГО РЕГУЛИРОВАНИЯ В СФЕРЕ ОБРАЗОВАТЕЛЬНЫХ УСЛУГ УКРАИНЫ}

Аннотация. Раскрывается проблема государственного регулирования высшего образования Украины. В первую очередь акцентируется внимание на процессе евроинтеграции при выборе особенностей и направлений развития высшего образования в стране.

Рассматриваются понятия государственного управления и образования как текущего процесса реформирования в сфере образовательных услуг, в частности - высшего образования Украины. Отмечается, что государственное управление призвано удовлетворять образовательные потребности общества для достижения стратегических целей его развития и экономики в целом. При этом образование выступает как объект исполнительной власти и характеризуется интеграцией со всем общественным строем, что в свою очередь требует исполнения государственного регулирования за ее организацией.

Акцентируется внимание на том, что государственное управление должно направляться на регулирование порядка организации учебного процесса, контролировать качество образования, а также устанавливать порядок лицензирования и государственной аккредитации заведений высшего образования. Тем самым указывается на важную роль управления высшим образованием в Украине.

Кроме того определены и изучены органы исполнительной власти в сфере государственного управления образованием, их функции и основные полномочия по отношению к предоставлению образовательных услуг в стране. Определяя задачи государственных органов управления сферой образования, проводится сравнительный анализ с европейскими странами и особен- 
ностями их институционального и функционального состояния государственного управления системой высшего образования.

В заключении отмечаются основные проблемные места в отечественном опыте государственного управления системой высшего образования, называя среди них отсутствие автономности заведений высшего образования и низкий уровень деятельности общественных консультативных органов, которые призваны создавать рекомендации по развитию системы высшего образования в стране, тем самым делая его более эффективным и качественным.

В итоге, определяется, что для реализации организационно-правового механизма государственного управления высшим образованием необходимо последовательно совершать организационные и правовые действия, которые опираются на объективные законы и направлены на реформирование системы образования.

Ключевые слова: система образования, высшее образование, государственное управление, качество образования, реформирование образования, процесс евроинтеграции.

Problem statement. The last decade in our country is characterized by significant socioeconomic changes and political reforms that have affected virtually all spheres of society. This also applies to higher education, where these changes take place very dynamically and at a high pace.

Today, Ukraine is on the path of European integration and is trying to actively participate in the development of the European educational space. That is why in this issue an important place is occupied by public administration bodies in the field of educational services. And this is especially true of their effective functioning, their peculiarities of interaction with each other, competent and correct definition of goals for innovative development of higher education, which in turn affects the activities of all institutions of higher education. The activity of resear- chers, sociologists and managers in the problems of reforming and functioning of the educational services in the field of studying state regulation is to increase the role of education and the reproduction of realistic socio-cultural public life, as well as in the economic and intellectual development of our state.

\section{Analysis of recent publications on} research issues. The question of the analysis of the current state of the system of state administration of higher education in Ukraine is highlighted in the scientific works of K. Andriychuk, S. Grigansky, V. Viktorov, S. Dombrovsky, D. Dvinkchuk, V. Kremen, V. Lugovoi, I. Sikorsky, V. Sichenka, A. Skidina and others.

Purpose of the article. In studying organizational, legal and other provisions and theoretical conclusions that characterize the specifics of the sphere 
of educational services as an object of public administration, to determine the peculiarities of state regulation of this sphere as one of the perspective directions of the state educational policy.

Presenting the main material of research. The latest policy of Ukraine in the context of reforming the educational system is expressed in various innovations that appear in innovative projects and programs for the development of the field of educational services of higher education, and pursues the main goal of improving the quality of educational services provided by modern schools [1].

Among the peculiarities of the implementation of higher educational services in the conditions of the reform of the domestic market of education, one should note the departure from the state administrative regulation in the relations between social actors, and in contrast, the application of methods of economic and regulatory regulation and their interaction at different levels. From this position, state regulation of the sphere of educational services is viewed more effectively than public administration, because it corresponds best to the socioeconomic significance of the educational sector in the modern society.

For the disclosure of tasks in this article, it is necessary to determine the content of the basic definitions of "state regulation" and "education".

State regulation in the educational sphere is a complex of socioeconomic, regulatory, organizational and other methods of directing influence on agents of the educational space, in order to provide favorable conditions for meeting educational needs and achiev- ing strategic goals of social development. This interpretation of state regulation in the context of considering educational issues is rather widespread and does not cause a serious discussion in the scientific community [2].

And education is a complex of interconnected industries that provide social and cultural services related to education, transfer and acquisition of knowledge, as well as the development of professional skills in work.

The Law of Ukraine "On Education" says that education is a deliberate process of education and training in the interests of man, society, and the state, which is accompanied by a statement of achievements. At the same time, this law states that obtaining education is the achievement and confirmation of a certain educational level and is certified by the relevant document.

Thus, among the responsibilities of the state, the need to support various forms of education and self-education is emphasized. Moreover, education, being an object of executive power, is characterized by deep integration with the whole social system. In the sphere of education, one third of the population is employed as consumers of educational services [3].

So, we can say that education is an area that traditionally has a high level of state regulation, therefore, the nature of the main part of relations in the field of education is administrativelegal. In other words, the rules of administrative law regulate the organization of the educational process, control the quality of education, and establish the procedure for the establishment, licensing and state accreditation of educational organizations. In addition, the 
rules of administrative law determine the order and management of state or municipal educational organizations, the regulation of relations between the educational activities of executive authorities.

In our country, higher education authorities are involved in the management of higher education at different levels. Today in the hands of the state there are the main levers of influence on the educational sphere, namely, the higher importance belongs to the state administration of higher education. Such a process has the organizing, purposeful and regulatory influence of the state on the system of higher education, which has a function of executive and regulatory nature. This management takes place in the process of implementing state power through specially authorized bodies that apply state power and perform certain management functions, which streamlines public relations in the field of higher education, achieves the goals and improves the structure and organization of the educational process [4].

Summarizing the above, it is worth saying that it is the public administration that is assigned the main role in the management of higher education in our state, which is provided by the various levels of government, which have an internal organization and which have appropriate powers in relation to institutions of higher education, as well as public administration.

One of the main points is that there should be a clear legal framework for the activities of state bodies of government. Today, such a legal basis in our country is the laws and regulations, namely, the Constitution of Ukraine, the Law of Ukraine "On Education", "On Higher Education", the National Doctrine on the Development of Education, as well as the decrees of the President of Ukraine and the Verkhovna Rada resolution for the sake of Ukraine, the Cabinet of Ministers of Ukraine, which are aimed at regulating the sphere of higher education.

To bodies which have been granted the function of management of higher education in accordance with Art. 11 of the Law of Ukraine "On Education" include: the Ministry of Education and Science of Ukraine, the ministries and departments of Ukraine, which are subject to institutions of higher education, the Higher Attestation Commission of Ukraine, local bodies of executive power and bodies of local self-government and subordinate management, departments of education. The Act also covers the responsibilities of state executive bodies that manage education. Also, the decrees of the President of Ukraine and resolutions of the Cabinet of Ministers, both normative and individual, influence the industry. For each educational and profile level, the Cabinet of Ministers of Ukraine approves the state standards, which specify requirements for the content, volume and level of education and professional training in our state. It is these standards that are used to assess the educational and profile levels of citizens, regardless of the form of the received education. Once every 10 years, state standards may be subject to revision and re-approval. The Ministry of Education and Science of Ukraine is the main state and central body, which has the right to manage the whole industry. 
In accordance with Art. 12 of the Law of Ukraine "On Education" and Regulation № 773/2000 on the Ministry of Education and Science of Ukraine are assigned the following tasks:

- to participate in the definition of state policy in the field of education and science, as well as in the training of highly skilled personnel, to develop programs for the development of education in general and state education standards;

- to establish state standards of knowledge on each subject;

- to determine the minimum standards of financial and logistical support of institutions of higher education;

- to carry out educational and methodological guidance and control over observance of state standards of education, as well as state inspection;

- to conduct state accreditation of institutions of higher education regardless of the forms of ownership and subordination, to issue licenses and certificates to them;

- develop draft regulations for institutions, which will be further approved by the Cabinet of Ministers of Ukraine;

- to carry out the management of state institutions of higher education of Ukraine.

Higher education institutions are also subordinated to the ministries and central executive authorities, which, together with the Ministry of Education and Science of Ukraine, carry out state policy in the field of education, science and professional training of highly skilled personnel. At the same time, the data of ministries and other central authorities subordinate to institutions of higher education take acts within their competence. They are ob- ligatory for the local authorities of the state executive power and local selfgovernment bodies, as well as subordinated educational management bodies and higher education institutions of a defined profile, regardless of ownership [5].

The work of the Higher Attestation Commission of Ukraine, provided in accordance with Art. 13 of the Law of Ukraine "On Education". She organizes and conducts the certification of scientific and scientific and pedagogical staff, conducts leadership on the award of scientific degrees and assigns scientific degrees to a senior researcher. Local state administrations and local self-government bodies are given the authority to form education management bodies, which in turn are directed at the management of institutions of higher education that are owned by communal property, the organization of teaching and methodological support of universities, improvement and improvement of professional qualifications of pedagogical workers, as well as their retraining and conduct certification, control the established requirements regarding content, level and volume of education, carry out attestation of teaching municipal institutions that are in communal ownership.

Today, the Ministry of Education and Science of Ukraine is responsible for reforming education in our country, providing an appropriate level of education that will be competitive in Europe and in the world, as well as achieving world standards in order for graduates of Ukrainian higher education institutions to meet the level of skills and knowledge and their employment in various spheres of domestic 
production, and their diploma was recognized abroad [6].

If we consider the European experience in terms of the institutional and functional component of public administration in the system of higher education, the following should be noted. Among the majority of European countries, and this applies to our state, all responsibility for the higher education sector lies with the profile ministry or the central governing body, in different countries it is called differently. In the UK it is called the Department of Higher Education, Innovation and Arts, in Norway and Finland - the Ministry of Education and Science, in France - the Ministry of Higher Education and Research.

To regulate the higher education sector, many regional-level functions in the management of institutions of higher education are assigned to intermediary agencies, public administration bodies, and a sufficiently large range of competences are granted to institutions of higher education that already have the appropriate autonomy [7].

In the analysis of our domestic experience of public administration, a higher education system, we cannot yet boast such a result. In our country, on a legislative level, the autonomy of institutions of higher education is determined, but in reality we do not observe this. Also in the system of governance of the field of higher education and in order to take into account possible interests included public advisory bodies, which should include: the Public Humanitarian Council under the President of Ukraine, the Public Council under the Ministry of Education and Science. One of the important units in the struc- ture of public bodies that have a significant impact on the higher education sector is the Union of Rectors of Higher Education Institutions. structurization is characteristic of their activities, but it is worth noting that it is still not quite high enough and not effective enough because their recommendations do not find a place in the practical implementation of public administration by the system of higher education.

Conclusions and prospects for further research. Summarizing the above, one should say that the implementation of the organizational and legal mechanism is possible only with the consistent implementation of organizational and legal actions, which will be based on objective laws and basic principles, and will have a purposefulness and functional definition with the use of appropriate methods, which will be aimed at achieving the goal.

In order to achieve the objectives of public administration, in addition to organizational and legal regulation, it is necessary to provide the field of higher education with resources that are important to include financial, personnel, logistical and informational. If we consider the branch of higher education in the context of the mechanisms of public administration, budget financing will be the most important lever of the influence of our state on the whole system of education in general and on separate educational institutions.

Therefore, for the effective functioning of the entire education system and the possibility of its continuous development, an important point is the proper organization of funding for educational institutions by the state and its full support. 


\section{REFERENCES}

1. Vavrenyuk S. A. (2018). Suchasnij stan ta problemi dvorivnevoyi strukturi $\mathrm{v}$ sistemi vishoyi osviti Ukrayini [The current state and problems of the twotier structure in the system of higher education of Ukraine]. Law and Public Administration: a collection of scientific works. Issue 3 (2). p. 11-15.

2. Dombrozska S. N. (2011). Mehanizmi realizaciyi derzhavnoyi politiki $\mathrm{v}$ galuzi vishoyi osviti [Mechanisms for the implementation of state policy in the field of higher education]. Actual problems of public administration. № 2. p. 107-113.

3. Plakhotnik O. V. (2015). Garmonizaciya nacionalnoyi ta yevropejskoyi osviti v suchasnih umovah yih reformuvannya [Harmonization of national and European education in the current conditions of their reform]. Sb. sciences Troops' troops. other Kiev. nats unth them Taras Shevchenko. Issue 50. p. 344-351.

4. Tovkanets O. (2016). Menedzhment osviti v politici formuvannya yevropejskoyi osvitnoyi strategiyi [Management in the Policy of the Formation of a European Educational Strategy]. Nauk. Visn Uzhhorod nats un-t Series: Pedagogy. Social work. Issue 2. p. 257-262.

5. Gedikova N. P. (2016). Derzhavna politika u sferi vishoyi osviti Ukrayini v konteksti yevropejskih osvitnih standartiv [State policy in the sphere of higher education of Ukraine in the context of European educational standards]. Contemporary society. Issue 1. p. 4-17.

6. Sukharnikov Yu. (2014). Normativnopravovi pidstavi dlya modernizaciyi vishoyi osviti v Ukrayini [Normativelegal grounds for the modernization of higher education in Ukraine]. Higher School. № 10. p. 20-39.

7. Horuzhi G. (2016). Institucijni zasadi yevropejskoyi vishoyi osviti [Institu- tional Principles of European Higher Education]. Higher School. № 11/12. p. 28-42.

\section{СПИСОК ВИКОРИСТАНИХ ДЖЕРЕЛ}

1. Вавренюк С. А. Сучасний стан та проблеми дворівневої структури в системі вищої освіти України / С. А. Вавренюк // Право та державне управління: збірник наукових праць. Запоріжжя: Вид-во Класичний приватний ун-т, 2018. - Вип. 3 (2). - C. 11-15.

2. Домбровська С. М. Механізми реалізації державної політики в галузі вищої освіти / С. М. Домбровська / / Актуальні проблеми держ. упр. 2011. - № 2. - C. 107-113.

3. Плахотнік О. В. Гармонізація національної та європейської освіти в сучасних умовах їх реформування / О. В. Плахотнік // Зб. наук. пр. Військ. ін-ту Київ. нац. ун-ту ім. Тараса Шевченка. - 2015. - Вип. 50. C. 344-351

4. Товканеиь О. Менеджмент освіти в політиці формування європейської освітньої стратегії / О. Товканець // Наук. вісн. Ужгород. нац. ун-ту. Серія: Педагогіка. Соціальна робота. 2016. - Вип. 2. - С. 257-262.

5. Гедікова Н. П. Державна політика у сфері вищої освіти України в контексті європейських освітніх стандартів / Н. П. Гедікова // Сучас. суспільство. - 2016. - Вип. 1. C. 4-17.

6. Сухарніков Ю. Нормативно-правові підстави для модернізації вищої освіти в Україні / Ю. Сухарніков // Вища шк. - 2014. - № 10. - С. $20-$ 39.

7. Хоружий $Г$. Інституційні засади європейської вищої освіти / Г. Хоружий // Вища шк. - 2016. № $11 / 12$. - C. $28-42$. 